UDC 339.94

\title{
THE BELT AND ROAD INITIATIVE: THE SIGNIFICANCE OF THE CHINESE RAILWAY EXPRESS TRAINS
}

\section{Chan Man Hung, Thomas}

Professor, Director of the One Belt One Road Research Institute, Chu Hai College of Higher Education, Hong Kong. Email: mhchan@chuhai.edu.hk

Introduction. Belt and Road Initiative of China is not something novel. It is the present-day continuation of the millennium-old Eurasian Silk Road that had been disrupted by the colonial expansion of the European powers. After the Cold War even the US and EU have attempted to restore the old Silk Road but with limited success. It was only in 2013 when the Chinese Government announced the Initiative that the world, not just the great powers, has begun once again to speak and think of the revival of the old Silk Road with enthusiasm.

Main research results. The Chinese government sees the Initiative only as initiative, intending it to be collective efforts for all interested countries for collective benefits. Of course, China will take the lead and it has pooled all its overseas investment projects under it and initiated even more especially through the newly established Asian Bank of Infrastructure Investment, plus its other overseas investment vehicles, including the Silk Road Fund. Apart from investment projects that help underdeveloped countries that have not won the favours from international agencies and multinational corporations, China has been rebuilding the lapsed Eurasian connectivity overland and restoring the networking multi-modal transport system of the old Silk Road (Figure 1).

These have taken the form of China-Europe and China-Central Asia Express Freight trains (officially named as China Railway Express). The service started in 2011 as block trains for foreign companies in China. With the launch of the Belt and Road Initiative, local governments in China have competed to set up new routes for the new overland Eurasian connections. Local governments have used subsidies to encourage corporate uses of the new transport option. Cities like Chengdu and Chongqing in western China and Wuhan and Zhengzhou in central China, which have been far outside of the economically dynamic coastal regions, have leveraged on the availability of the convenient means for Eurasian links to attract overseas investment for export markets in Europe, and have been successful. The resulting increases in tax revenues have more than compensated for the freight subsidies.

Figure 1

The network system of the old Silk Road that connected China, India and Central Asia with Rome in Europe

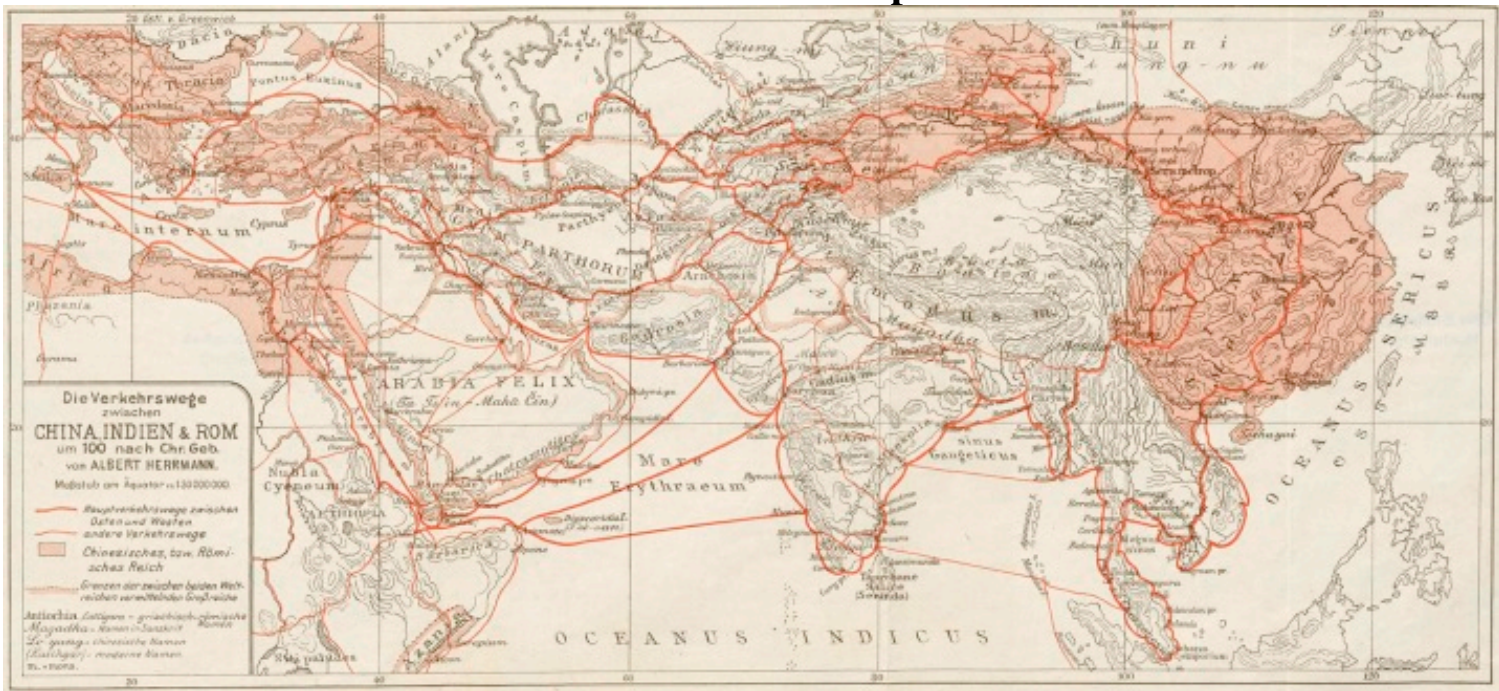

Source: [Herrmann, 1922], reproduced in [Galli, 2017]. 
Their successes have provided a strong demonstrative effect on other Chinese cities. Freight routes have thus proliferated (Figure 2) and they have promoted further their uses by Chinese and foreign firms with greater number of options of routes and schedules. Since 2011, the number of trains per year has jumped from 17 to 12,400 in 2020 (Table 1). Their share in Eurasian freight volume has come from almost non-existent to probably a few and even closing to 10 percentage points during the global pandemic in 2020 and early 2021.

Figure 2

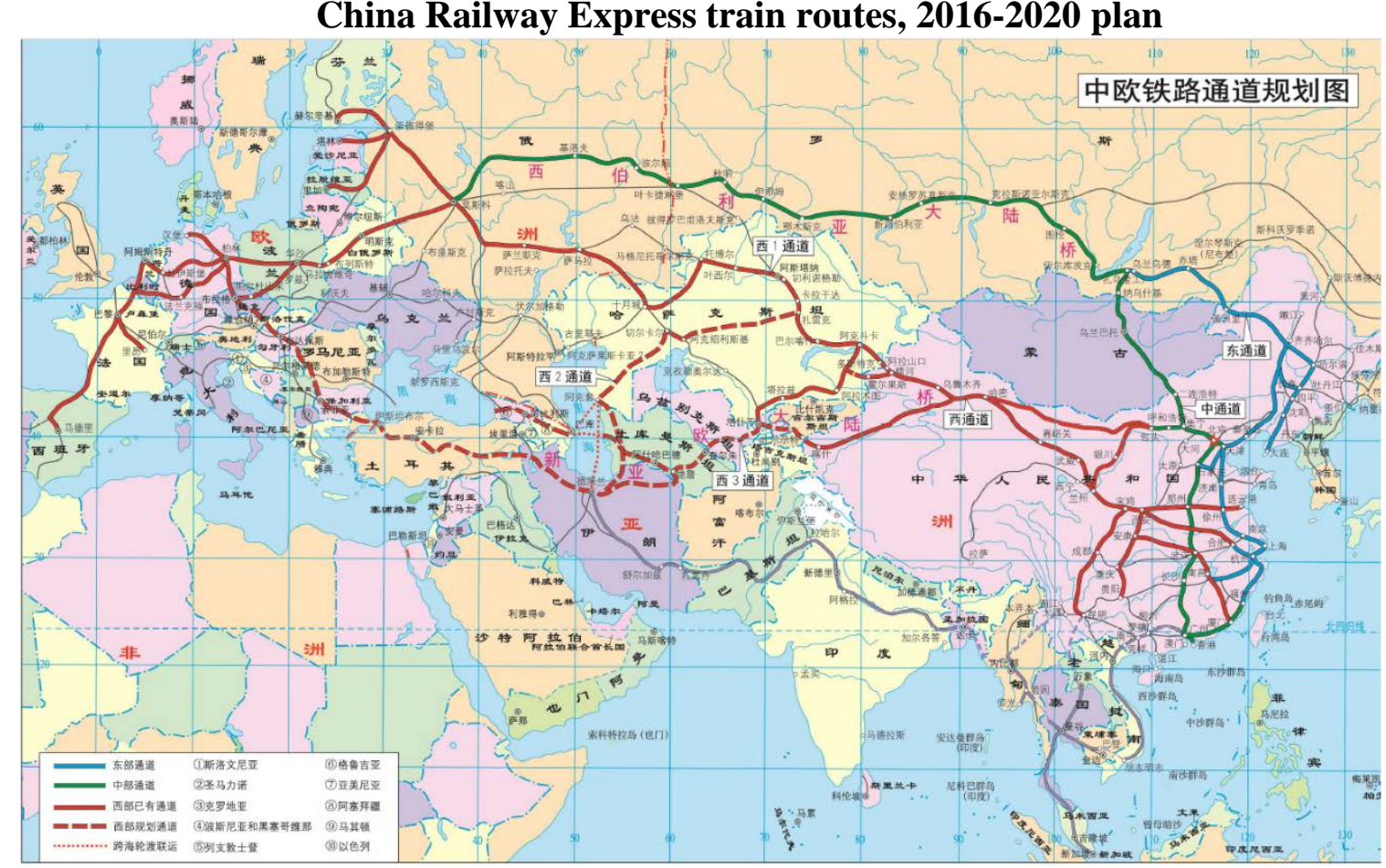

Source: [Chinese Government, 2016].

Note: The map shows only the current situation and vision of the development in 2016 by the Chinese government. It has not incorporated the recent southern extension of the intermodal connections of China Railway Express routes originated in Chengdu and Chongqing to Baohai ports and Chinese overland borders with countries in the Indo-China Peninsula plus the coming passage through the China-Lao Railway that will be in operation in 2021 and the Thai railways under construction. There are also a route from China to ports of the Persian Gulf from Tehran, a new China-Kyrgyzstan-Uzbekistan Road-Rail Connection launched in 2020, and another road rail link through Tibet to Nepal.

Table 1

The growth of China Railway Express trains, 2011-2020

Source: China State Railway Group Co., Ltd.

\begin{tabular}{|c|c|}
\hline Year & No. of trains \\
\hline 2011 & 17 \\
\hline 2012 & 42 \\
\hline 2013 & 80 \\
\hline 2014 & 308 \\
\hline 2015 & 815 \\
\hline 2016 & 1,720 \\
\hline 2017 & 3,673 \\
\hline 2018 & 6,300 \\
\hline 2019 & 8,255 \\
\hline 2020 & 12,400 \\
\hline
\end{tabular}


The global pandemic shows the importance of China Railway Express in filling the gap when both the conventional air and sea transport fail. The sudden explosion of demands helps to break the stubbornness and inertia as well as vested interests of governments and firms to explore the new (in fact the revival of the old) options of Eurasian linkage. The inter-continental transport scene has long been dominated by oligarchies. The routing, stops and hubs, fares, and the vessels used serve mainly the profits and competitive advantages of the dominating parties with little regard to SMEs and developing countries and economies. The opening of the overland routes provides an alternative that could benefit those that have seldom been served by the big carriers and agents. After two or three centuries of negligence, the overland routes would need massive investment to build the necessary infrastructural facilities and institutional arrangement to compete even at a disadvantage with the well-established system of sea transport. The Chinese initiative to at least partially divert the transport of its overseas trade and to invest politically and economically is crucial for making the overland alternative possible and viable.

Compared with container shipping which has increasingly relied on scale economy and caters therefore manly for mass production of large corporations, freight trains have the advantages of smaller scale, greater frequency in schedules, shorten traveling time (hence lower capital costs and speed to the market), all of which serve very well smaller firms with smaller scale of production and smaller batches of cargoes to be shipped. One could say the container shipping is a product of mass production and mass consumption of standard commodities typical of the American version of capitalism, whereas freight trains serve flexible mode of production of quality and of greater variety and limited production that may represent Post-Fordism. In addition, trains could have many stops in the journey for uploading and offload cargoes, whereas large container ships normally have few stopovers and in the case of Eurasian transport could have little cargoes back on the Europe to Asia trips. Freight trains' lower scale economy is often more than compensated by their flexibility. In particular in supply chain management, freight trains like China Railway Express excel in the facilitation for integrated management (the entire logistic network within the supply chain could be constantly customized according to the market situation), flexible routing, special role of nodes, inter-modality, and regular transport services.

At present, the basic framework for the trade route structure of the old Silk Road could still be found but lacks upgrading and modernization. To compete with sea transport that utilizes state of art technology and management, any revival of the overland and intermodal Silk Road needs massive investment to realize its general and niche advantages. China's Belt and Road Initiative is the answer to the need and the China Railway Express is instrumental in reviving, repairing and further improving with innovations the millennium old Eurasian connectivity. The Chinese initiative has already attracted similar efforts by countries along the old Silk Road.

In 2020, 29 cities in China had over 100 direct China Railway Express trains running in the year with the five major hub cities contributed more than half of the trains. This means that almost most of the cities in China are connected with and have access to the Eurasian service by the domestic railway system and by intermodal means. Over 90 cities in 20 plus countries in Europe have been served by the Chinese intercontinental services, the farthest being London across the British Strait, and covering the four corners of Europe in a network fashion. Towards the end of 2020 some Chinese cities had launched super express services of freight trains at $300 \mathrm{~km} / \mathrm{hour}$ running on the high-speed railway tracks for passengers. They were for domestic delivery of ecommerce orders. They would easily be converted to become a domestic leg of China Railway Express trains, thereby reducing further the journey time before crossing the national borders.

Apart from routes going into Europe, the new iron Silk Road has also branched into Central Asia, entering the ports in the Persian Gulf with an onward journey by seas to coastal regions of the Indian Ocean. In the last few years, the China Railway Express trains coming from Europe have continued to go to countries in Southeast Asia either by existing railways to Vietnam and in the coming year to Laos via the China-Laos Railway that would come into operation at the end of this 
year, or by ships to the Philippines, Indonesia, and Singapore. The end of 2020 also saw the launch of a rail-truck route across Tibet into Nepal.

More significantly, even Japan and Korea have been using the China Railway Express trains for sending their export cargoes by sea to Chinese coastal ports and onboard trans-continental Chinese trains to Europe. Nippon Express, Japan's top logistics company, is scheduled to double the freight trains it operates between China and Europe in 2020. Currently it runs 23 round trip routes using the China Railway Express services. Rail accounted for only about $10 \%$ of Nippon Express' total cargo transported between these two regions in 2019. The room for expansion would be very great. In view of the potential business opportunities, Danish company A.P. Moller - Maersk, the world's largest container-shipping operator, has offered a combination of a short-sea and intercontinental rail transport for permanent weekly service since September 2020. The service takes cargoes from ports in South Korea, Japan, or China to the port of Nakhodka in the Russian Far East via sea, then transports it by train to northern Europe via the Trans-Siberian Railway.

The competition with the Chinese services will in fact supplement the Chinese initiative, especially since the explosion of rail transport demands in 2020 has overloaded the various Eurasian routes from within China. The move of the Japanese and Danish logistics firms confirms the market confidence in the Eurasian transport trade. Such a new development has transformed the role of China in the Belt and Road Initiative and in the globalization process of the world economy. China is more than the production base for world demanded products and the market for imported goods by virtue of its being the largest manufacturing economy and market in the world. It is emerging as the strategic intermodal transport hub for trade and exchanges with East Asia in the east, Southeast Asia in the south and Central Asia, West Asia, Europe, and Africa in the west. The shift in Eurasian trade is just the beginning.

There are also possible strategic changes to the Eurasian trade flow pattern by the improved inter-modality of the new Silk Road. The role of the Greek port of Piraeus used by the Chinese shipping companies to join the sea transport from the East via the enlarged Suez Canal with the socalled Balkan Silk Road by trucks and rail would pose a strong challenge to the century-old route terminated at Atlantic ports of Europe, in particular Rotterdam and Amsterdam. The Piraeus option presents a more direct and speedier overland approach to other parts of Europe and cuts short the overall traveling time of cargoes from a wide area in the East. This would complement the various routes from Asia into Europe via Belarus, Poland, Ukraine, Hungary and even the Baltic ports and most recently Turkey. The Eurasian trade flow would be less going through a circular pattern through the Mediterranean Sea and entering Europe from the Atlantic seaboard moving westward. The old Silk Road trade flow directly from the East to the West is now revived and will probably reveal its competitiveness in the coming years when old infrastructures are restored and improved, thanks to the Chinese Belt and Road Initiative and the economic impacts of China Railway Express trains.

The Chinese initiative has a strong demonstration effect on other countries. In terms of railway links, many other countries have, for their own reasons and in response to the opportunities created by the Chinese efforts, launched ambitious investment projects. The early success of Kazakhstan in straightening its domestic east-west rail link has cut short the traveling of Eurasian trains traversing the country. The BTK (Baku in Azerbaijan, Tbilisi in Georgia, Kars in Turkey) Railway was completed in 2017. From 2020 it has begun to serve as the middle route of the new Silk Road going all the way from the East in China and Central Asia to the European part of Turkey through the new Marmaray tunnel line beneath the Bosphorus Strait that continues to Erdirne at the border with Greece \& Bulgaria. The Russian is also planning to upgrade the Trans-Siberia Railway, which carries now half of the cargoes to Europe from East Asia. Even the EU is increasing its efforts to modernize its Trans European Transport Network in particular the Eastern corridors to compete perhaps with the Chinese funded Budapest-Belgrade Railway (part of the Balkan Silk Road from Piraeus) now under construction.

The Chinese initiative and its immediate consequence in the past few years have unleashed a competition for infrastructure investment first for railway and for all possible transport modes as 
well. The Lapis Lazuli route that predated the old Silk Road by thousands of years has been revived by the joint efforts of Turkey, Afghanistan, Turkmenistan, Azerbaijan, and Georgia. Negotiation started in 2012, before the Chinese initiative, but agreement was only signed in 2017 and the project has been inaugurated in December 2018. Once in operation it has been incorporated into the new Silk Road as during the times of the old Silk Road.

Conclusions. The old Silk Road was not about politics, but about the desires of societies for trade and exchange and connectivity of all kinds. Similarly, the new Silk Road in the form either of China's Belt and Road Initiative or other programmes of other countries and regional organizations should be about trade, exchange and collectivity of people and ideas. The progress in the past few years seems to confirm this, even though more efforts need to be done by all parties concerned and interested in.

\section{References}

1. A. Herrmann. (1922). Die Verkehrswege zwischen China, Indien und Rom um 100 nach Chr. Geb: Originalkarte in Zweifarbendruck mit Erläuterndem

2. Chan Man Hung, Thomas. (2018). The Belt and Road Initiative - the New Silk Road: a research agenda. Journal of Contemporary East Asia Studies, 7:2, pp. 104-123. https://doi.org/10.1080/24761028.2019.1580407

3. Chan Man Hung, Thomas (with Louise do Rosário). (2017, March). Pearl River Delta: From World Factory to Global Innovator, Instituto Internacional de Macau, Macau.

4. Chan Man Hung, Thomas. (2016, 14 May). 'The Belt and Road Strategy of China and the Asian LDCs', presented at the workshop on 'Economic sectors in landlocked developing countries', the United Nations 'Economic and Social Commission for Asia and the Pacific (ESCAP) and the Deutsche Gesellschaft für Internationale Zusammenarbeit, Bangkok, Thailand.

5. Chan Man Hung, Thomas. (2015, July). Study on the Role and Functions of Hong Kong in China's One-belt One-road Strategy, Central Policy Unit, Hong Kong Special Administrative Region Government.

6. Marco Galli. (2017). Beyond frontiers: Ancient Rome and the Eurasian trade networks. Journal of Eurasian Studies, 8, pp. 3-9.

7. Office of the Leading Group for the construction of 'One Belt and One Road', Chinese Government. 'China Railway Express construction and development plan (2016-2020)' promulgated on 19 October 2016.

8. Thomas Chan, et al. (2018, February). "China's Belt and Road Initiative - The role of Macao and the Portuguese-speaking countries”, International Institute of Macau, pp. 11-44.

9. Étienne de la Vaissière. (2014). China before Capitalism, in The Cambridge History of Capitalism, vol. 1, The Rise of Capitalism: From Ancient Origins to 1848, Larry Neal \& Jeffrey G. Williamson, eds., Cambridge University Press.

10. UN Economic Commission for Europe. (2020). Euro-Asian Transport Linkages: Operationalisation of inland transport between Europe and Asia, Geneva. 


\section{MICT}

\section{ПОЛІТИЧНІ ПРОБЛЕМИ МІЖНАРОДНИХ ВІДНОСИН}

\section{Ignatiev P. M.}

The United Arab Emirates: What is behind economic miracle?

\section{Berezovska I.}

Dynamics of implementation of The Association Agreement between Ukraine and the EU: prospects and new challenges

Chechelashvili V. K.

South Caucasus in the Network of International Relations .28

Shevchenko O. V.

The role of the civil society in global climate challenges combating. .44

\section{СУЧАСНА СИСТЕМА МІЖНАРОДНОГО ПРАВА}

\section{Antonovych M.}

Individual and Collective Intent in the Crime of Genocide (on the example of the HolodomorGenocide against the Ukrainian Nation)

\section{ОСОБЛИВОСТІ РОЗВИТКУ СВІТОВОГО ГОСПОДАРСТВА ТА МЕВ}

\section{Shnyrkov O. I. ,Pliushch D. S.}

Potential and role of underserved foreign markets for the development of Ukraine's trade with the EU.

\section{Dziuba P. V., Shtogrin K. V.}

Home bias as a key behavioral deviation of portfolio investors decisions

\section{Chan Man Hung, Thomas}

The belt and road initiative: the significance of the Chinese railway express trains .83 


\section{АКТУАЛЬНІ ПРОБЛЕМИ МІЖНАРОДНИХ ВІДНОСИН}

\section{Збірник наукових праць}

\section{ВИПУСК 145}

Заснований в 1996 році.

Засновник : Інститут міжнародних відносин

Київського національного університету імені Тараса Шевченка.

Свідоцтво про державну реєстрацію: К1 №292 від 05.11.1998 p.

Перересстрація у 2020 році.

Засновник: Киӥвський національний університет імені Тараса Шевченка.

Свідоцтво про державну ресстрацію: серія КВ №24308-14148ПР від 13.02.2020 р.

Науковий редактор: Дорошко М. С., доктор історичних наук, професор.

Рекомендовано до друку Вченою радою Інституту міжнародних відносин Київського національного університету імені Тараса Шевченка. Протокол № 5 від 22 грудня 2020 року.

\section{Підписано до друку 28.12.2020 року.} Наклад 100 примірників

Інститут міжнародних відносин

Київського національного університету імені Тараса Шевченка

Тел. 044-481-44-68

Сайт: http://apir.iir.edu.ua/index.php/apmv/ 